\title{
Hydrostatic pressure induces expression of interleukin 6 and tumour necrosis factor $\alpha$ mRNAs in a chondrocyte-like cell line
}

Kenji Takahashi, Toshikazu Kubo, Yuji Arai, Isao Kitajima, Masaharu Takigawa, Jiro Imanishi, Yasusuke Hirasawa

\begin{abstract}
Objective-To clarify the effect of pressure on the expressions of proteoglycan core protein and metabolism related cytokines in a chondrocyte-like cell line, HCS-2/8. Methods-HCS-2/8 cells were exposed to $1,5,10$, or $50 \mathrm{MPa}$ of hydrostatic pressure (HP) for two hours, and mRNA expressions of interleukin 6 (IL6) and tumour necrosis factor $\alpha$ (TNF $\alpha)$ were examined by using reverse transcription-polymerase chain reaction (RT-PCR) method with specific primer sets; and mRNA of proteoglycan core protein, stromelysin, and tissue inhibitor of metalloproteinase 1 (TIMP1) were measured with northern blotting.

Results-HP exposure caused temporal morphological changes of the cells, but did not affect cellular viability. IL6 and TNF $\alpha$ mRNA expressions were not observed in the control cells under the atmospheric pressure, whereas in the cells treated with HP, pressure dependent enhancement of IL6 mRNA expression was observed between 30 minutes and four hours after the HP release. TNF $\alpha$ mRNA expression also increased 30 minutes after the exposure to $50 \mathrm{MPa}$ of $\mathrm{HP}$ and disappeared four hours later. Proteoglycan core protein mRNA levels increased between 30 minutes and four hours after the exposure to 1 or $5 \mathrm{MPa}$ of $\mathrm{HP}$, whereas the levels decreased after 10 or $50 \mathrm{MPa}$ of HP. Stromelysin and TIMP1 mRNA signals did not respond to HP.

Conclusions-HP at excessively high levels induced IL6 and TNF $\alpha$ expression and reduced the expression of proteoglycan core protein, while physiological levels of HP increased the expression of proteoglycan core protein. These findings are important when considering the pathology of osteoarthritis.

(Ann Rheum Dis 1998;57:231-236)
\end{abstract}

Articular cartilage is an important component of the joint, and it is always exposed to pressure produced by weight bearing and muscle contraction. Cartilage matrix mainly consists of proteoglycan and collagen, and this realises a cushioning effect of the matrix against mechanical stresses. However, if the mechanical stresses are increased to a level excessively higher than the physiological levels, cartilage matrix will be impaired and osteoarthritis (OA) could occur. This process of disease progression is confirmed by the fact that (a) clinical deformation in OA starts from the weight bearing area, ${ }^{1}$ and (b) many OA related animal models are prepared by making mechanical changes on the joints. ${ }^{23}$ Chondrocytes play an important part in the metabolism and maintenance of cartilage matrix, therefore, it is quite important to elucidate how chondrocytes respond to pressure.

Recently, as a cause of onset and progression of OA, locally produced humoral factors, for example, cytokines and proteases, have been considered important, in addition to mechanical stresses. Among them, tumour necrosis factor $\alpha(\mathrm{TNF} \alpha)$ and interleukin 6 (IL6) were reported to be upregulated in cartilage of an experimental OA model or OA patients. ${ }^{45}$ $\mathrm{TNF} \alpha$ promote connective tissue degradation through the inhibition of extracellular matrix synthesis, and induces expression of collagenase and stromelysin in chondrocytes, as well as interleukin $1 \beta .{ }^{6}$ IL6 plays a prominent part in the coordinated systemic host defence response to injury. IL6 production in chondrocytes markedly increases when IL $1 \beta, \mathrm{TNF} \alpha$, or transforming growth factor $\beta 1$ (TGF $\beta 1$ ) are present $^{7}$; and IL6 induces tissue inhibitor of metalloproteinase 1 (TIMP1). ${ }^{8}$

However, to our knowledge, the pathology of OA has not been investigated in terms of the relation between pressure and cytokine expression. This prompted us to examine whether mechanical stress changed non-matrix chondrocyte expression, such as expression of OA related cytokines.

This study investigated the effect of pressure in mRNA expression of proteoglycan core protein, cytokines such as $\mathrm{TNF} \alpha$ and IL6, which are implicated in $\mathrm{OA},{ }^{9}$ stromelysin, and TIMP1, by using a chondrocyte-like cell line, HCS $-2 / 8,{ }^{11}{ }^{11}$ which can be subcultured and possesses characteristic features of normal chondrocytes.

Table 1 Cytokine specific oligonucleotide primers for PCR

\begin{tabular}{lllll}
\hline Cytokine & Primer & Position & cDNA & Reference \\
\hline IL6 & S & $242-261$ & 819 & 15 \\
& AS & $4535-4554$ & & \\
TNF $\alpha$ & S & $1521-1540$ & 468 & 16 \\
& AS & $2270-2289$ & & \\
$\beta$ actin & S & $103-122$ & 540 & 17 \\
& AS & $619-642$ & &
\end{tabular}

S: sense. AS: antisense.
Accepted for publication 27 February 1998 

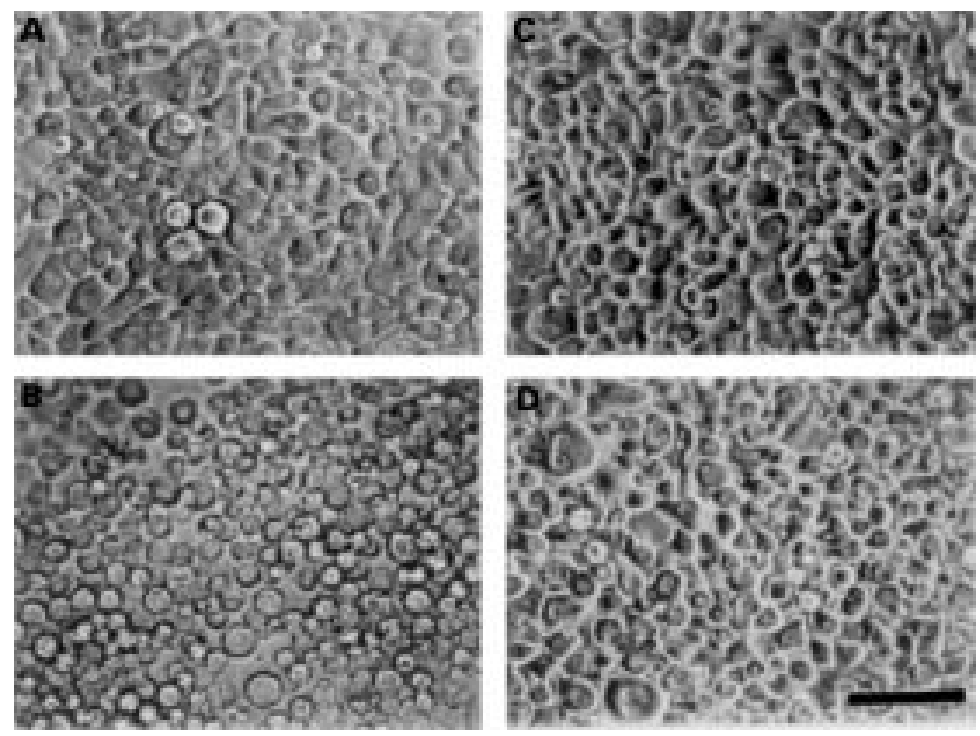

Figure 1 Morphological changes of HCS-2/8 after exposure to HP. Phase contrast photomicrograms of cells cultured in DMEM containing $10 \%$ FBS after HP exposure. (A) Control cells under atmospheric pressure. (B) Thirty minutes after applying $50 \mathrm{MPa}$ of $H P$. (C) Twenty four hours after applying $50 \mathrm{MPa}$ of HP. (D) Thirty minutes after applying 5 $\mathrm{MPa}$ of HP. Bar = $100 \mu \mathrm{m}$.

A

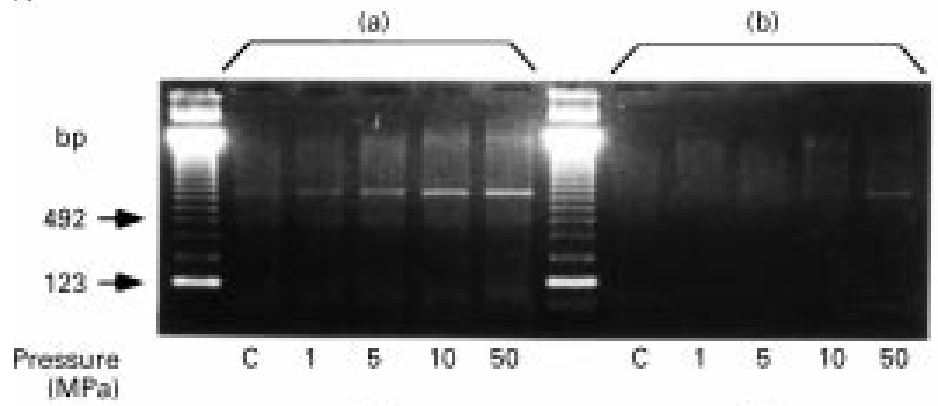

(c)

(d)

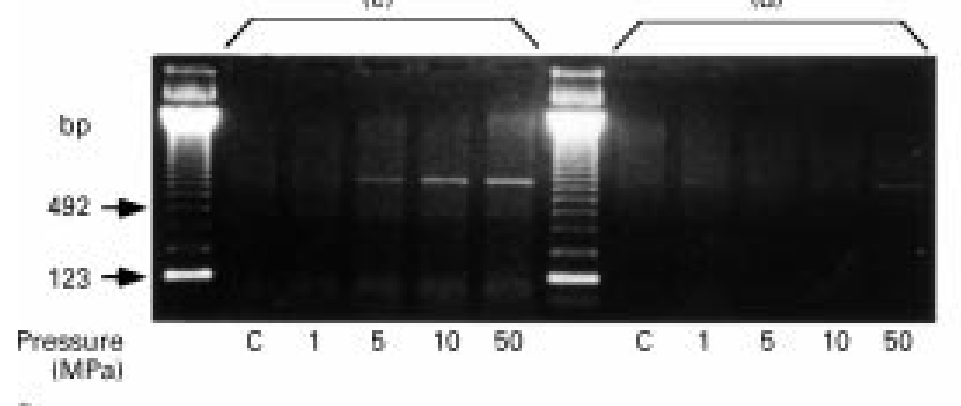

8

(a)
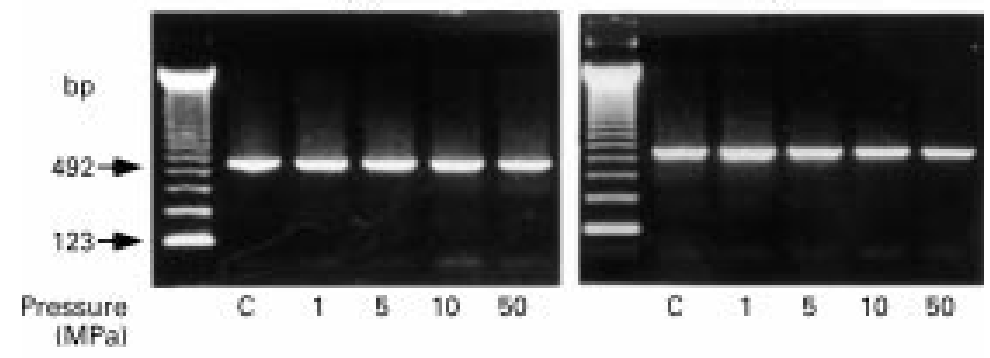

Figure 2 Pressure dependent enhancement of IL6 $m R N A$ expression. (A) IL6 RT-PCR products from the cells at 30 minutes $(a)$ and $(b)$ and four hours $(c)$ and $(d)$ after HP exposure. Two point five microgram (a) and (c) and $1 \mu \mathrm{g}(\mathrm{b})$ and (d) of total RNA were reverse transcribed in $10 \mu \mathrm{l}$ reaction mixture. (B) $\beta$ actin RT-PCR products from the cells at 30 minutes (a) and two hours (b), which confirm cDNA isolation. One microgram of total $R N A$ was reverse transcribed in $10 \mu \mathrm{l}$ reaction mixture. $C$ : control cells treated under the atmospheric pressure.

\section{Methods}

CELL CULTURE

HCS-2/8 cells were seeded in $60 \mathrm{~mm}$ plastic Petri dishes (Falcon Plastic Corp, Oxnard, $\mathrm{CA})$, at a density of $2.0 \times 10^{6}$ cells $/ 3 \mathrm{ml}$ of Dulbecco's modified Eagle's medium (DMEM: Nissui Pharmaceutical Co, Tokyo, Japan) containing $10 \%$ fetal bovine serum (FBS: GIBCO BRL Co, Gaithersburg, MD), $60 \mu \mathrm{g} / \mathrm{ml}$ of kanamycin, and $0.292 \mathrm{mg} / \mathrm{ml}$ of L-glutamine (Wako Pure Chemical Industries Ltd, Osaka, Japan). The cells were maintained at $37^{\circ} \mathrm{C}$ in a humidified atmosphere of $5 \%$ $\mathrm{CO}_{2}$. The medium was changed twice a week.

PRESSURE APPLICATION

The cells reached confluence after approximately one week of culture, and then they were exposed to hydrostatic pressure (HP) ranging from $1 \mathrm{MPa}$ to $50 \mathrm{MPa}$ as previously described. ${ }^{12}$ The Petri dishes were placed in a deformable Teflon pouch, which was filled with serum free DMEM containing the same concentrations of kanamycin and L-glutamine as mentioned above, and packed completely after removing air bubbles. The pouch then was placed in a stainless steel pressurisation vessel, exposed to $1,5,10$, or $50 \mathrm{MPa}$ of $\mathrm{HP}$ for two hours. After depressurisation, $3 \mathrm{ml}$ of fresh serum free DMEM was given to each Petri dish, and the dish was maintained at atmospheric pressure in the air containing $5 \% \mathrm{CO}_{2}$, until analysis. Cells seeded in Petri dishes and placed in the same apparatus under the same conditions but not treated with HP exposure were used as non-pressurised controls.

ANALYSIS OF CYTOKINES AND PROTEOGLYCAN CORE PROTEIN MRNA IN THE CONTROLS AND HP EXPOSED CELLS

Total RNA was extracted from the controls and $\mathrm{HP}$ exposed cells between 30 minutes and eight hours after HP exposure by using the acid guanidinium thiocyanate-phenol chloroform method. ${ }^{13}$ The RNA preparations were analysed with a reverse transcription-polymerase chain reaction (RT-PCR) method for mRNA expressions of IL6 and TNF $\alpha$; and with northern blotting for mRNA expressions of proteoglycan core protein, stromelysin and TIMP1. $\beta$ actin mRNA expression was examined by both RT-PCR and northern blotting, to ensure the quality of the RNA preparation and to prove the reliability of RT-PCR and northern blot protocols used in this study. RT-PCR assay was performed as previously described. ${ }^{14}$ Specific primer sets for IL6, TNF $\alpha$, and $\beta$ actin were designed based on the published sequence data. ${ }^{15-17}$ Table 1 summarises their primer positions. Each of the four doses of total RNA (0.2, 1, 2.5, and $5 \mu \mathrm{g}$ ) was reverse transcribed with oligo (dT) 16 primer by using MoMuLV RNase H-reverse transcriptase (GIBCO BRL Co, Gaithersburg, MD) in $10 \mu \mathrm{l}$ reaction mixture under the conditions recommended by the manufacturer. Specific sequences of cytokine mRNAs were amplified by using specific primers for them and Taq DNA polymerase (Wako Pure Chemical Industries), as previously described. ${ }^{14}$ RT-PCR products 


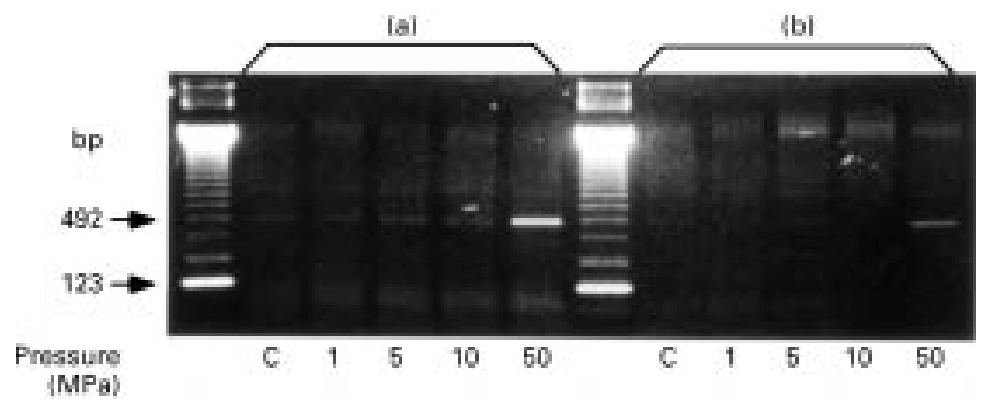

Figure 3 Induction of TNFa mRNA expression after HP exposure. The cells at 30 minutes after the exposure to $50 \mathrm{MPa}$ of HP expressed TNFa mRNA. Two point five microgram (a) and $1 \mu \mathrm{g}$ (b) of total RNA were reverse transcribed in $10 \mu \mathrm{l}$ reaction mixture. No TNFa mRNA expression was detected in the cells between four and eight hours after HP exposure. C: control cells treated under the atmospheric pressure. were analysed in ethidium bromide containing agarose gels and evaluated for the expression of each cytokine's mRNA.

Northern blotting was performed as described elsewhere. ${ }^{18}$ The total RNA $(7 \mu \mathrm{g})$ was fractionated in a formaldehyde containing agarose gel, transferred to a nylon membrane, and prehybridised. The prehybridisation mixture was replaced with fresh solution containing $200 \mathrm{ng} / \mathrm{ml}$ of probes. Hybridisation was performed overnight at $65^{\circ} \mathrm{C}$. Chemiluminescent detection by using DIG luminescent detection kits (Boehringer-Mannheim Biochemica, Mannheim, Germany) and Renaissance nucleic acid chemiluminescence reagent kit (DuPont NEN) was performed according to the manufacturer's specifications. Kodak
A

Proteoglycan core protein

fo actin

Pressure (MPs)
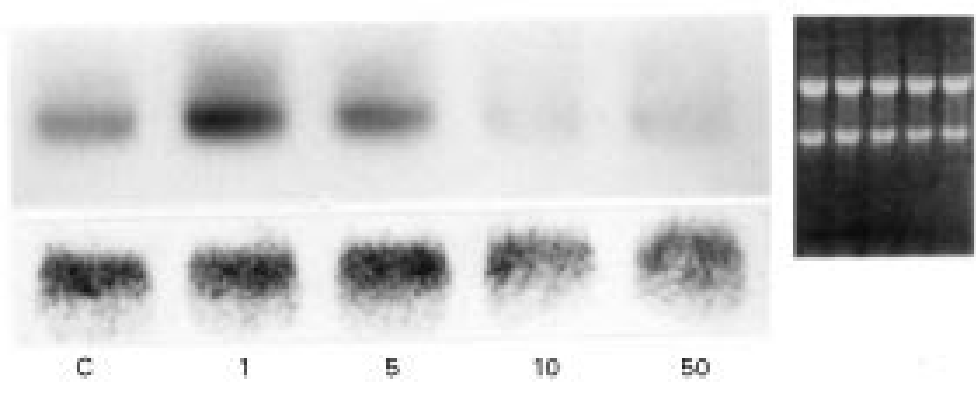

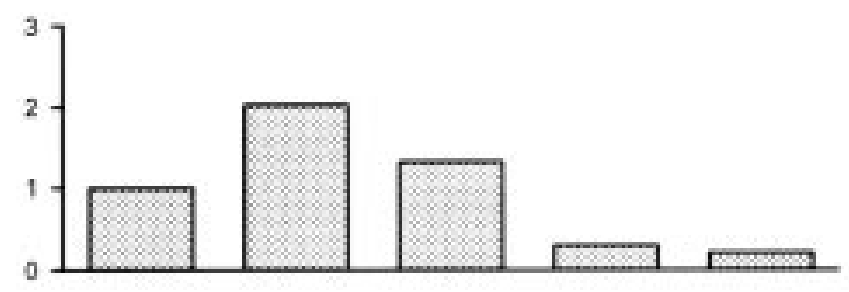

B

Proteoglycan core protein

Sactin

Pressure (MPa)

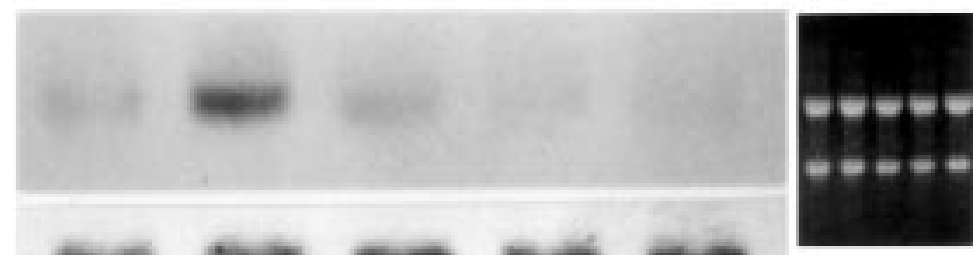

1

5

10

50

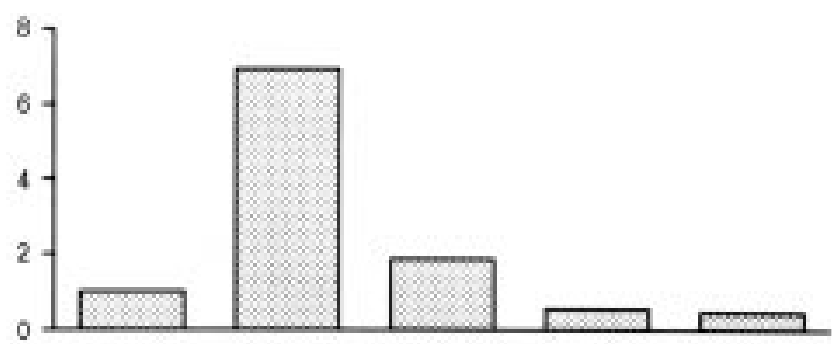

Figure 4 Effect of HP exposure on proteoglycan core protein $m R N A$ expression. Cells were exposed to 1, 5, 10 or $50 \mathrm{MPa}$ of HP for two hours, and total RNA was extracted at 30 minutes $(A)$ and four hours $(B)$ after the release of HP. Equal amounts of total RNA were fractionated by gel electrophoresis, transferred to a nylon membrane, and hybridised to RNA probes. For quantification, the signals were measured by using a densitometor. A photograph of gel staining (right side) shows equal amounts of RNA were applied. $\beta$ actin $m R N A$ expression is also shown. C: control cells treated under the atmospheric pressure. 
XAR films were exposed to the nylon membranes for 5 to 30 minutes, and the films were analysed by using a densitometor, comparing the relative mRNA level of several samples on a single blot. We confirmed equal volumes of RNA were loaded by checking the intensity of ethidium bromide stained $18 \mathrm{~S}$ and $28 \mathrm{~S}$ rRNA bands. RNA loading was also examined by probing for $\beta$ actin mRNA. The RNA probes for proteoglycan core protein, stromelysin, TIMP1, and $\beta$ actin mRNA were prepared as described in a previous study. ${ }^{19}$

\section{Results}

In all duplicated or triplicated experiments for each test item, almost identical results were obtained. Figures are those of the representative case of the repeated experiments.

MORPHOLOGY OF HCS-2/8 CELLS AFTER HP EXPOSURE

After HP exposure, the cells were observed under a phase contrast light microscope. The HCS-2/8 cells have a polygonal shape under atmospheric pressure (fig 1A). This shape changed to almost spherical after the exposure to $50 \mathrm{MPa}$ of $\mathrm{HP}$ for two hours (fig $1 \mathrm{~B}$ ). After the pressure was released, the cells regained their original polygonal shape within 24 hours (fig 1C). The cells that were exposed to lower magnitudes of HP ( 5 to about $10 \mathrm{MPa}$ ), demonstrated milder morphological changes (fig 1D), and returned to the polygonal shape soon after the pressure release. Exposure to $1 \mathrm{MPa}$ of $\mathrm{HP}$ resulted in less morphological changes on the cells. Examination by using trypan blue dye exclusion assay showed that cellular viability was not affected by these HP levels.

EFFECTS OF HP ON CYTOKINE MRNA EXPRESSIONS IN HCS-2/8 CELLS

All PCR products having an expected size are evaluable in the agarose gel. mRNAs for $\beta$ actin were clearly detected at a constant level in all samples. After the exposure to $1,5,10$, or 50 $\mathrm{MPa}$ of HP for two hours, total RNAs were isolated from the cells and analysed identically by using PCR. IL6 mRNA and TNF $\alpha$ mRNA expressions were not observed in the control cells treated under the atmospheric pressure. In the PCR assays using various RNA concentrations, pressure dependent enhancement of IL6 mRNA expression on the cells was observed between 30 minutes and four hours after HP exposure (fig 2). No IL6 mRNA expression was observed eight hours after HP. $\mathrm{TNF} \alpha \mathrm{mRNA}$ expression was also increased at 30 minutes after the exposure to $50 \mathrm{MPa}$ of $\mathrm{HP}$ and disappeared four hours after the release of HP (fig 3).

Northern blotting was performed to analyse the expressions of proteoglycan core protein, stromelysin, and TIMP1 in the cells exposed to $1,5,10$, or $50 \mathrm{MPa}$ of HP. Expression of $\beta$ actin mRNA was found at an almost constant level in all samples. Proteoglycan core protein was detected in the cells grown under the atmospheric pressure, and its mRNA levels were increased 30 minutes and four hours after the exposure to $1 \mathrm{MPa}$ or $5 \mathrm{MPa}$ of $\mathrm{HP}$. In particu-

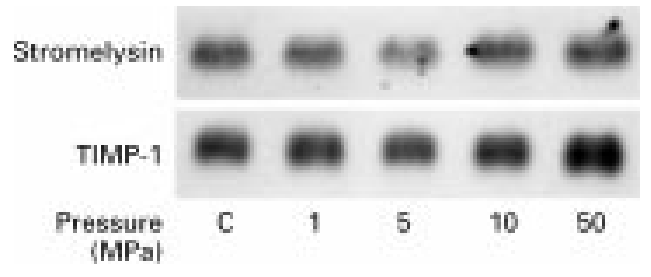

Figure 5 Stromelysin and TIMP1 $m R N A$ signals in HCS-2/8 cells after HP exposure. Representative signals at four hours after HP exposure are shown. C: control cells treated under the atmospheric pressure.

lar, the signal level for this mRNA in the cells exposed to $1 \mathrm{MPa}$ was increased sixfold four hours after the release of HP. On the other hand, in the cells exposed to $10 \mathrm{MPa}$ or 50 $\mathrm{MPa}$ of $\mathrm{HP}$, proteoglycan core protein mRNA levels decreased 30 minutes and four hours after the release of HP (fig 4). At eight hours, the mRNA levels returned to almost the same as those under atmospheric pressure. Stromelysin and TIMP1 mRNA signals did not show major response to HP during eight hours after the release of HP (fig 5).

\section{Discussion}

The effect of some types of pressure, for example, tension, ${ }^{20}$ shearing force, ${ }^{4}$ and $\mathrm{HP},{ }^{21-23}$ has been studied using tissue sections ${ }^{21} 22$ and cultured cells. ${ }^{23} \mathrm{HP}$ is considered to have the most influential effect on the metabolism of cartilage. ${ }^{24} \mathrm{~A}$ recent study ${ }^{25}$ demonstrated that chondrocytes and extracellular matrix in different zones of a tissue react differently to mechanical loading. Although tissue culture better represents in vivo conditions, direct compressive force given to cartilage tissue will result in such phenomena as deformation of tissues and cells, ${ }^{26}$ effusion of tissue fluid, ${ }^{27}$ and increase of proteoglycan levels followed by the increase of cation. ${ }^{24}$ These factors will affect experimental results, and make the analysis of pressure effect quite difficult. Therefore, we used cultured cells, instead of tissue sections, in the investigations of the effect of HP on the expression of metabolism related cytokines.

HCS $-2 / 8$ is a chondrosarcoma cell line, established in 1989 by Takigawa et al. ${ }^{10} \mathrm{HCS}-2 / 8$ produces Type II, IX, and XI collagens, as well as cartilage type proteoglycan (aggrecan), as seen in normal chondrocytes. In addition, the reaction of $\mathrm{HCS}-2 / 8$ to various vitamins and growth factors is similar to those of normal chondrocytes. ${ }^{11}$ This cell line can maintain these characteristics of normal chondrocytes for a long culture period, and can be a useful model of human chondrocytes. Our study, for the first time, demonstrated that HP can induce expression of IL6 and TNF $\alpha$ mRNAs in the cultured cells that possess characteristic features of normal chondrocytes. In the measurements using RT-PCR, IL 6 and TNF $\alpha$ mRNA expressions in the control cells without giving exposure to HP were all negative, while the expressions became positive after exposure to HP regardless of the RNA concentrations and this change was reproducible. Therefore, our RT-PCR findings were evaluated to be valid.

During walking, pressure on a human hip joint ranges between $3 \mathrm{MPa}$ and $10 \mathrm{MPa} .{ }^{28} \mathrm{It}$ 
sometimes reaches approximately $20 \mathrm{MPa}^{29}$ and the level varies continuously. In a pathological condition, for example, OA, much higher HP could occur. We previously reported $^{12}$ that constant $50 \mathrm{MPa}$ of $\mathrm{HP}$ induced heat shock protein in HCS-2/8, the expression of which is increased in OA cartilage, ${ }^{30}{ }^{31}$ and this magnitude of HP adversely affects the metabolism of these cells. Therefore, constant $50 \mathrm{MPa}$ was considered to represent an abnormally high and pathological level of stimulus. IL6 and TNF $\alpha$ have been considered as cytokines that are induced by inflammation or immune reactions. In this study, these cytokines were also induced after exposure to a unphysiologically high pressure level, $50 \mathrm{MPa}$. This indicates that IL6 and TNF $\alpha$, which are increased in OA chondrocytes, can be induced by unphysiologically high, excessive pressure. This is important when considering the mechanism of OA development because of an extremely high pressure level.

In this study, cell morphology changed to spherical after giving $50 \mathrm{MPa}$, while this change was mild under low pressure levels. On the other hand, IL6 mRNA expression was most noticeable at $50 \mathrm{MPa}$. Our findings on morphological changes after applying HP agree with those of previous studies, and show cytoskeletons, such as actin filament, changed under the HP. ${ }^{32}{ }^{33}$ Mohtai et al reported that 1.6 $\mathrm{Pa}$ of fluid-induced shear induced the expression of IL6 mRNA and IL6 protein, ${ }^{4}$ and chondrocytes exposed to fluid induced shear for 48 hours appeared to be elongated and elliptical and their major axes aligned primarily circumferentially. ${ }^{34}$ On the other hand, cytoskeletons, for example, actin filament, are believed to be involved in the mRNA expression and play quite an important part in the local expression and function of mRNA. ${ }^{35-37}$ These findings suggest that changes in actin filament could be involved closely with IL6 induction by mechanical stress. In the same way, the changes in actin filament could also be involved in $\mathrm{TNF} \alpha$ induction under $50 \mathrm{MPa}$ of HP. Mechanotransduction of cells has been reported by many researchers, and it is thought that ion channels take an important part in the initial response to mechanical stress, and changes in intracellular calcium ion concentrations and cAMP production are largely involved in the regulation of gene expression caused by mechanical stress. ${ }^{38}$ It has been hypothesised that mechanical stress is transferred from extracellular matrix to nuclei via cytoskeleton, which is connected to integrins on cellular surface. ${ }^{39}$ In OA cartilage tissues, the number of chondrocytes that are in the dynamic process of polymerisation and depolymerisation of cytoskeleton elements, is reported to be increased..$^{40}$ Buschmann et $a l^{41}$ demonstrated the importance of cell matrix interaction in the cellular reaction against pressure by using the primary chondrocyte/agarose culture. HCS-2/8 in plate culture and at a confluent level is reported to express integrin and to generate large volume of chondrocyte-like matrix, and this matrix is accumulated around the cell. ${ }^{102}$ In this study, we loaded HP to
HCS-2/8 at a confluent level, but this cell at a sparse or subconfluent level reacted less apparently to HP (unpublished data). Therefore, we consider that integrin and extracellular matrix may also take an important place in the present findings.

Cytoskeleton may also be involved in the regulation of proteoglycan synthesis in chondrocytes. ${ }^{43}$ We previously reported that 1 or 5 $\mathrm{MPa}$ of $\mathrm{HP}$ induced an increase of ${ }^{35} \mathrm{~S}$ sulphate uptake into chondrocyte-like cells, and 10 or $50 \mathrm{MPa}$ of $\mathrm{HP}$ induced a decrease. ${ }^{12}$ In this study, expression of proteoglycan core protein mRNA increased after giving 1 or $5 \mathrm{MPa}$ of $\mathrm{HP}$, and it decreased after giving 10 or $50 \mathrm{MPa}$. This change in the expression volume caused by HP was larger than the changes in ${ }^{35} \mathrm{~S}$ sulphate uptake. On this point, CS-Szabo et al reported that changes in the levels of proteoglycan core protein mRNA were severalfold greater than expected. ${ }^{44}$ Therefore, our findings on proteoglycan core protein mRNA are thought to be consistent to the previous findings, and as shown in another study, ${ }^{45}$ this shows that HP affects extracellular matrix production on transcriptional level. $\mathrm{TNF} \alpha$ is reported to induce IL $6,{ }^{6}$ but in the present study, expression of TNF $\alpha$ mRNA occurred transiently immediately after the exposure to HP. Therefore, we cannot conclude whether TNF $\alpha$ directly induced IL6. Our chronological findings also suggest that these cytokines would not affect proteoglycan expression.

In this study, HP did not affect the expression of stromelysin and TIMP1 mRNAs, and this was in contrast with our expectation. In OA, imbalance between proteases and inhibitors is thought to be implicated, ${ }^{46}$ but constant HP for two hours did not influence the imbalance at transcriptional level. We also reported $^{12}$ that HP increased the expression of TGF $\beta 1$, which can induce TIMP $1,{ }^{47}$ and shear stress to chondrocytes is reported to increase TIMP1 mRNA expression. ${ }^{34} \mathrm{TNF} \alpha$ increases stromelysin expression, ${ }^{6}$ and IL6 increases TIMP1 expression. ${ }^{8}$ The difference between our findings and expectation could be attributable to the constant HP used in this study, and to the monitoring of mRNAs after the exposure to HP. We applied constant pressure instead of cyclic pressure, because our purpose was to isolate the specific regulatory signals after giving abnormal pressure. Because Smith et a ${ }^{45}$ reported that cells react to cyclic pressure more noticeably than to constant pressure, future studies using cyclic HP and that monitor gene and protein expressions would be of interest. In addition, HCS $-2 / 8$ is not only a chondrocytelike cell line but also a transformed cell line, and transformed cell lines are known to be resistant to HP in comparison to primary cultures. ${ }^{48}$ To better understand our findings, mRNA studies should be repeated in primary chondrocyte cultures. Monitoring the IL6 and TNF protein productions in addition to mRNA, and comparison between IL6 induction by HP and that by such an inflammatory cytokine as IL1, merit future studies. 
This study received a grant in aid for scientific research from the Ministry of Education, Science, and Culture of Japan.

1 Dippe P, Kirwan J. The localization of osteoarthritis. Br J Rheumatol 1994;33:201-4.

2 Muir H, Carney SL. Pathological and biochemical changes in cartilage and other tissues of canine knee resulting from induced joint instability. In: Helminen HJ, Kirivanta I Tammi M, Saamanen A-M, Paukkonen K, Urvelin J, eds foint loading: biology and health of articular structures. Bristol John Wright, 1987; 47-63.

3 Hoch DH, Grodzinsky AJ, Koob TJ, Albert ML, Eyre DR. Early changes in material properties of rabbit articular cartilage after menisectomy. J Orthop Res 1983;1:4-12

4 Mohtai M, Gupta MK, Donlon B, Ellison B, Cooke J, Gibbons $\mathrm{G}$, et al. Expression of interleukin-6 in osteoarthritic chondrocytes and effects of fluid-induced shear on this expression in normal human chondrocytes in vitro. J Orthop Res 1996;14:67-73.

5 Kammermann JR, Kincaid SA, Rumph PF, Baird DK, Visco DM. Tumor necrosis factor- $\alpha$ (TNF- $\alpha$ ) in canine osteoarthritis: Immunolocalization of TNF- $\alpha$, stromelysin and TNF receptors in canine osteoarthritic cartilage. Osteand TNF receptors in canine osteo

6 Tyler JA, Bolis S, Dingle JT. Mediators of matrix catabolism. In: Kuettner KE, Schleyerbach R, Peyron JG, Hascall VC, In: Kuettner KE, Schleyerbach R, Peyron JG, Hascall VC, eds. Articular cartilage
Press, 1992: 251-64.

7 Guerne PA, Carson DA, Lotz M. IL-6 production by human articular chondrocytes: modulation of its synthesis by cytokines, growth factors, and hormones in vitro. J Immunol 1990;144:499-505.

8 Lotz M, Guerne PA. Interleukin-6 induces the synthesis of tissue inhibitor of metalloproteinases-1/erythroid potentiating activity (TIMP-1/EPA). J Biol Chem 1991;266: 2017-20

9 Venn G, Nietfeld JJ, Duits AJ, Brennan FM, Arner E, Covington $\mathrm{M}$, et al. Elevated synovial fluid levels of interleukin-6 and tumor necrosis factor associated with early experimental canine osteoarthritis. Arthritis Rheum 1993;36:819-26.

10 Takigawa M, Tajima K, Pan H-O, Emoto M, Kinoshita A, Suzuki F, et al. Establishment of a clonal human chondrosarcoma cell line with cartilage phenotypes. Cancer Res 1989:49:3996-4002.

11 Enomoto MI, Takigawa M. Regulation of tumor-derived and immortalized chondrocytes. In: Adolphe $\mathrm{M}$, ed Biological regulation of the chondrocytes. Boca Raton: CRC Press, 1992:321-38

12 Takahashi K, Kubo T, Kobayashi K, Imanishi J, Takagawa $\mathrm{M}$, Arai $\mathrm{Y}$, et al. Hydrostatic pressure influences $\mathrm{mRNA}$ expression of transforming growth factor- $\beta 1$ and heat shock protein 70 in chondrocyte-like cell line. J Orthop Res 1997;15:150-8.

13 Chomcznski P, Sacchi N. Single-step method of RNA isolation by acid guanidinium thiocyanate-phenol-chloroform extraction. Anal Biochem 1987;162:156-9.

14 Sotozono C, Kinoshita S, Kita M, Imanishi J. Paracrine role of keratinocyte growth factor in rabbit corneal epithelial cell growth. Exp Eye Res 1994;59:385-92.

15 Yasukawa K, Hirano T, Watanabe Y, Muratani K, Matsuda $\mathrm{T}$, Nakai S, et al. Structure and expression of human B cell
stimulatory factor-2 (BSF-2/IL-6) gene. EMBO J 1987;6: 2939-45.

16 Shirai T, Yamaguchi H, Ito H, Todd CW, Wallace RB. Cloning and expression in Escherichia coli of the gene for human tumor ncrosis factor. Nature 1985;313:803-6.

17 Albino AP, Davis BM, Narus DM. Induction of growth factor RNA expression in human malignant melanoma: markers of transformation. Cancer Res 1991;51:4815-20.

18 Kobayashi K, Ohgitani E, Tanaka Y, Kita M, Imanishi J. Herpes Simple virus-induced expression of $70 \mathrm{kD}$ hea shock protein (HSP70) requires early protein synthesis but not viral DNA replication. Microbiol Immunol 1994;38 $321-5$

19 Arai Y, Kubo T, Kobayashi K, Takeshita K, Takahashi K, Ikeda $\mathrm{T}$, et al. Adenovirus vector-mediated gene transduction to chondrocytes: In vitro evaluation of therapeutic efficacy of transforming growth factor- $\beta 1$ and heat shock protein 70 gene transduction. J Rheumatol 1997;24:1787-95.

20 Dewitt MT, Handley CJ, Oakes BW, Lowther DA. In vitro response of chondrocytes to mechanical loading. The effect of short term mechanical tension. Connect Tissue Res of short term mect

21 Hall AC, Urban JPG, Gehl KA. The effects of hydrostatic pressure on matrix synthesis in articular cartilage. J Orthop Res 1991;9:1-10.

22 Lipiello L, Kaye C, Neumata T, Mankin HJ. In vitro metabolic response of articular cartilage segments to low levels of hydrostatic pressure. Connect Tissue Res 1985;13:99107.

23 Van Kampen GPJ, Veldhuizen JP, Kuijer R, van der Stadt RJ, Schipper CA. Cartilage response to mechanical forces studied in high density cultures. Arthritis Rheum 1985;28: 419-24.
24 Urban JPG. The chondrocyte: a cell under pressure. Br J Rheumatol 1994:33:901-8.

25 Wong M, Wuethrich P, Buschmann MD, Eggli P, Hunziker E. Chondrocyte biosynthesis correlates with local tissue strain in statically compressed adult articular cartilage. J Orthop Res 1997;15:189-96.

26 Broom ND, Myers DB. A study of the structural response of wet hyaline cartilage to various loading stresses. Connect Tissue Res 1980;7:227-37.

27 Mow VC, Holmes MH, Lai WM. Fluid transport and mechanical properties of articular cartilage. J Biomech 1984;17:377-94.

28 Afohe NYP, Byers PD, Hutton WC. Contact pressures in the human hip. J Bone Joint Surg Am 1987;69B:536-41.

29 Hodge WA, Fijan RS, Carlson KL, Burgess RG, Harris WH, Mann RW. Contact pressures in the human hip joint measured in vivo. Proc Natl Acad Sci USA 1986;83:287983

30 Takahashi K, Kubo T, Arai Y, Imanishi J, Kawata M, Hirasawa Y. Localization of heat shock protein in osteoarthritic cartilage. Scand J Rheumatol 1997;26:368-75.

31 Takahashi K, Kubo T, Goomer RS, Amiel D, Kobayashi K, Imanishi $\mathrm{J}$, et al. Analysis of heat shock proteins and cytokines expressed during early stages of osteoarthritis in a mouse model. Osteoarthritis Cartilage 1997;5:321-9.

32 Parkkinen JJ, Lammi MJ, Inkinen R, Jortikka $M$, Tammi $M$, Virtanen I, et al. Influence of short-term hydrostatic pressure on organization of stress fibers in cultured chondrocytes. J Orthop Res 1995;13:495-502.

33 Haskin C, Cameron I. Physiological levels of hydrostatic pressure alter morphology and organization of cytoskeletal and adhesion proteins in MG-63 osteosarcoma cells. Biochem Cell Biol 1993;71:27-35.

34 Smith LR, Donlon BS, Gupta MK, Mohtai M, Das P, Carter DR, et al. Effects of fluid-induced shear on articular chondrocyte morphology and metabolism in vitro. J Orthop Res 1995;13:824-31.

35 Fey EG, Ornelles DA, Penman S. Association of RNA with the cytoskeleton and the nuclear matrix. J Cell Sci Suppl 1986;5:99-119

36 Bagchi T, Lawson DE, Sells BH. Cytoskeletal association of muscle-specific mRNAs in differentiating L6 rat myoblast. Exp Cell Res 1987;168:160-72.

37 Lawrence JB, Singer BH. Intracellular localization of messenger RNAs for cytoskeletal proteins. Cell 1986;45: $407-15$.

38 Wright MO, Stockwell RA, Nuki G. Response of plasma membrane to applied hydrostatic pressure in chondrocytes and fibroblasts. Connect Tissue Res 1992;28:49-70.

39 Wang N, Butler JP, Ingber DE. Mechanotransduction across the cell surface and through the cytoskeleton. Science $1993 ; 260: 1124-7$.

40 Kouri JB, Jimenez SA, Quintero M, Chico A. Ultrastructural study of chondrocytes from fibrillated and nonfibrillated human osteoarthritic cartilage. Osteoarthritis Cartilage 1996;4:111-25.

41 Buschmann MD, Gluzband YA, Grodzinsky AJ, Hunziker EB. Mechanical compression modulates matrix biosynthesis in chondrocyte/agarose culture. J Cell Sci 1995;108: $1497-508$.

42 Tuckwell DS, Ayad S, Grant ME, Takigawa M, Humphries MJ. Conformation dependence of integrin-typeII collagen binding. Inability of collagen peptides to support $\alpha_{2} \beta_{1}$ binding, and mediation of adhesion to denatured collagen by a novel $\alpha_{5} \beta_{1}$-fibronectin bridge. J Cell Sci 1994;107: 993-1005.

43 Newman P, Watt FM. Influence of cytochalasin D-induced changes in cell shape on proteoglycan synthesis by cultured articular chondrocytes. Exp Cell Res 1988;178:199-210.

44 CS-Szabo G, Melching LI, Roughley PJ, Glant TT. Changes in messenger RNA and protein levels of proteoglycans and link protein in human osteoarthritic cartilage samples. Arthritis Rheum 1997;40:1037-45.

45 Smith LR, Rusk SF, Ellison BE, Wessells P, Tsuchiya K, Carter DR, et al. In vitro stimulation of articular chondrocyte mRNA and extracellular matrix synthesis by hydrostatic pressure. J Orthop Res 1996;14:53-60.

46 Dean DD, Martel-Pelletier J, Pelletier J-P, Howell DS, Woessner JFJ. Evidence for metalloproteinase inhibitor imbalance in human osteoarthritic cartilage. J Clin Invest 1989;84:678-85.

47 Gunter M, Haubeck H-D, van de Leur E, Blaser J, Bender $\mathrm{S}$, Gutgenann I, et al. Transforming growth factor $\beta 1$ regulates tissue inhibitor of metalloproteinases-1 expression in differentiated human articular chondrocytes. Arthritis Rheum 1994;37:395-405.

48 Dibb W, Morild E, Laerum OD. Effects of high pressure on normal and neoplastic rat cells in culture. Virchows Arch [Cell Pathol] 1981;38:169-76. 